\title{
OPTIMIZATION AND IMPROVEMENT IN STABILITY OF COUNTERFORT RETAINING WALL WITH RELIEF SHELF
}

\author{
Tonne V. $\mathbf{R}^{1}$, Mohite P. $\mathbf{M}^{2}$ \\ ${ }^{I}$ M. Tech Scholar, Civil Engineering Department, R. I. T., Sangli, Maharashtra, India \\ ${ }^{2}$ Associate Professor of Civil Engineering Department, R. I. T., Sangli, Maharashtra, India
}

\begin{abstract}
Reinforced concrete retaining walls are meant to support more height of earth mass. Cantilever retaining wall is constructed up to height of $6 \mathrm{~m}$ and above that it becomes uneconomical. To support more height of earth mass advancement is done in cantilever retaining wall by adding relief shelf in it. Due to provision of relief shelf the soil pressure on the retaining wall is reduced resulting in improvement in stability of retaining wall. Cantilever retaining wall with one relief shelf is economical up to height of $10 \mathrm{~m}$ above that counterfort retaining wall with relief shelf is useful. In this paper analysis and design of counterfort retaining wall with one relief shelf is done for various positions of relief shelf. These results are studied to get minimum earth pressure, more stability and minimum moment in each component of retaining wall. The optimization of counterfort retaining wall is done to get minimum size of retaining wall. Due to this optimization extra formation width is available in hilly areas and excessive cutting is avoided thereby construction cost reduces.
\end{abstract}

Keywords: Counterfort Retaining wall, relief shelf, earth pressure, Factor of safety, overturning, sliding, optimization $* * *$

\section{INTRODUCTION}

Retaining structures are the walls meant to support earth or other materials. In order to design retaining wall it is necessary to determine active and passive earth pressures on wall. In hills it is not possible to construct roads without retaining structures. Retaining structures are encountered and constructed in various fields of engineering such as roads, harbors, dams, subways, railroads, tunnels mines and military fortification.

According to Khural R. ${ }^{[2]}$ to achieve required formation width and to stabilize disturbed hill slopes number of retaining structures are constructed in hilly terrain, its construction cost is near about $20 \%$ to $30 \%$ of hill roads project cost. Gravity retaining walls are designed by considering its shape and size. Its stability is depending on its dimensions. Design of gravity retaining wall is not based on type of material used for construction. Ray Choudhari ${ }^{[1]}$ had concluded that when height of earth mass to be retained is less than $6 \mathrm{~m}$ cantilever retaining wall is generally preferred. Above $6 \mathrm{~m}$ height counterfort retaining wall is used to achieve economy in construction. Cantilever retaining wall with relief shelf is alternative to counterfort retaining wall which is found out easy to construct and more economic. As total active earth pressure on retaining wall with relief shelf is lower in magnitude than that of conventional type, keying at the base may not be necessary to prevent sliding in certain cases. Patil S. ${ }^{[4]}$ says that by providing relief shelf in cantilever retaining wall it is found that factor of safety against overturning and sliding is improved. Due to provision of relief shelf earth pressure reduces which results in reduction in section. As section of retaining wall is less, requirement of construction material is also less which results reduction in cost. He had found that reduction in volume of concrete and steel is $35 \%$ and $18 \%$ respectively. For height in the vicinity of $10 \mathrm{~m}$ cantilever retaining wall with single relief shelf is economical than conventional counterfort retaining wall but further economy is achieved by providing relief shelf in counterfort.

\section{COULOMB THEORY}

The Coulomb's theory is conveniently adopted when the plane of failure extending diagonally upward and backward through the backfill. The sliding wedge is a triangular mass of soil between this plane of failure and the back face of retaining wall. The soil within the sliding wedge would slump down when the retaining wall is suddenly removed. If a plane of failure makes an angle $Q$ with the horizontal, the forces acting on the sliding wedge are as shown in figure 1 . Forces acting on failure plane these forces consist of weight of the soil within the wedge $\mathrm{W}$ which acts through the centroid of the triangle, a thrust normal to the plane of failure $\mathrm{N}$ which exerted by the soil to the right of the failure plane. $\mathrm{N}=\mathrm{N} \tan Q$ will be at the limit of equilibrium. These forces must be balanced by the thrust $\mathrm{P}$ which is assumed to act horizontally and to be concurrent with $\mathrm{W}, \mathrm{N}$ and $\mathrm{S}$. The equal and opposite reaction to $\mathrm{P}$ is the lateral force to withstand which the wall is to be designed. The forces $\mathrm{N}$ and $S$ may be replaced by the resultant $R$ to derive the value of $\mathrm{P}$. S acts along a line making the angle $Q$ with the normal to the failure plane. Since $\mathrm{W}, \mathrm{P}$ and $\mathrm{R}$ are three concurrent forces which are in equilibrium, when the failure is about to take place along the failure plane, they may be represented by the triangle of forces in figure 1 . In this triangle $\mathrm{P}=\mathrm{W}$ $\tan \rho-\otimes=1 / 2 * \mathrm{Ka}^{*} \gamma * \mathrm{H}^{2}$ 


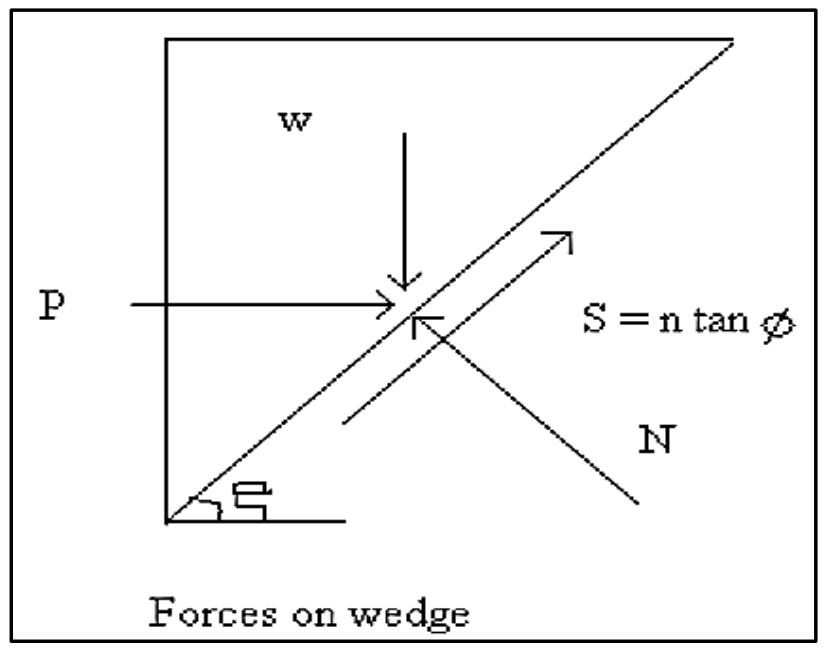

Fig.1 Forces acting on failure plane

Fig. 2 shows the active and passive state of plastic equilibrium in a non-cohesive soil with the horizontal ground surface. In an active state the major principal stress $\sigma_{1}$ is vertical and minor principal stress $\sigma_{2}$ is horizontal. Circle I represents such a state in which the pole P1 corresponds to minor principal stress while point A corresponds to major principal stress The circle touches the failure envelopes at F1 and F2' hence P1F1 and P1F1'show the directions of failure planes or slip lines these slip lines also shown in fig. 2. Similarly direction of the major principal stress and minor principal stresses are vice versa.

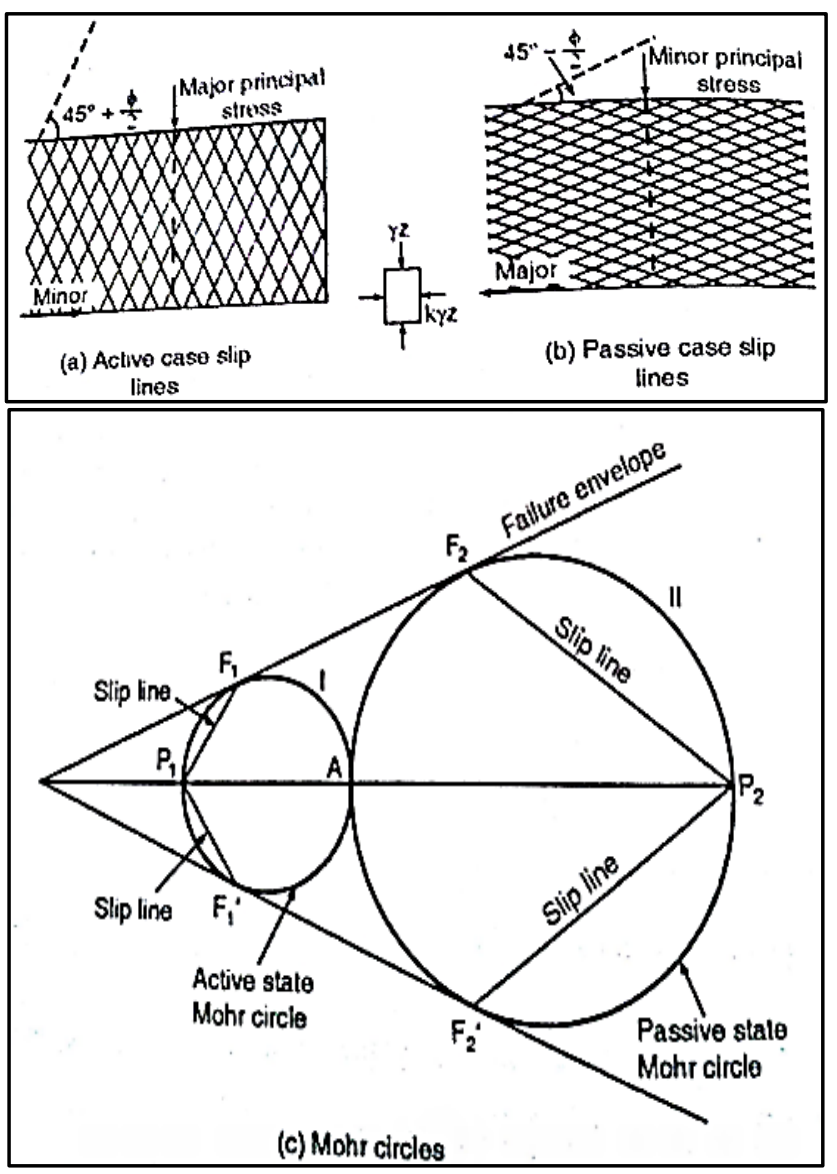

Fig.2 Active and Passive states of plastic equilibrium

\section{LOFT THEORY}

For non-cohesive soils the active earth pressure on a retaining wall can be computed by considering the stabilities of different wedges of soil mass. It attains a maximum value when the rupture plane makes an angle of $45^{\circ}+\alpha / 2$ with the horizontal, where $Q$ is the angle of internal friction of the non-cohesive soil. Fig 3 shows cross section of retaining wall with one horizontal shelf of width ' $b$ ' and thickness ' $t$ ' at a height ' $\mathrm{H}-\mathrm{h}$ ' from the base. When $\mathrm{b}=\mathrm{H}-\mathrm{T}-\mathrm{h} \tan \left[45^{\circ}+\right.$ $\otimes / 2$ ], the rupture plane originating at the intersection of base and stem on the backfill side meets the horizontal shelf. According to Jumikies the earth pressure distribution diagram below the shelf would be as shown in the fig. 3 , as if a free surface existed at the shelf level. If $b$ is greater than $\mathrm{H}-\mathrm{T}-\mathrm{h} \tan \left[45^{\circ}+\mathrm{Q} / 2\right]$, the rupture plane which gives the maximum value of lateral earth pressure, i.e. the plane inclined at $45^{\circ}+\alpha / 2$ with the horizontal, cannot develop, as it has to go through the shelf. The total active earth pressure at any level can be obtained by stability analysis of wedge, assuming that by providing a horizontal shelf, the weight of the earth over the shelf is born by the shelf and the weight of this soil mass is not effective to cause sliding.

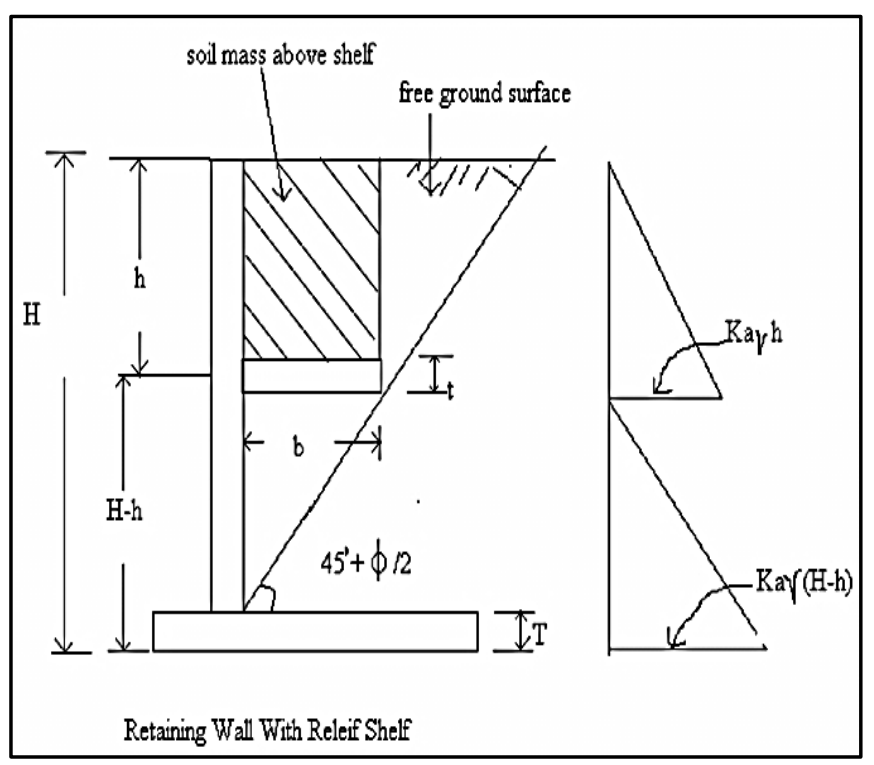

Fig.3 Cross section of retaining wall with one relief shelf and soil pressure on wall

\section{ANALYSIS OF COUNTERFORT RETAINING}

\section{WALL WITH ONE RELIEF SHELF}

From literature it is clear that cantilever retaining wall with one relief shelf is economical up to $10 \mathrm{~m}$ height, above that height counterfort retaining wall with relief shelf is economical. Analysis of counterfort retaining wall is done to find best suited position considering different heights of walls too. Properties taken for analysis are, Cohesiveness of soil $(c)=0 \mathrm{~N} / \mathrm{mm}^{2}$, Angle of internal friction $(Q)=30^{\circ}$, Inclination of soil $=0^{0}$, Unit Weight of soil $\left(\gamma_{\mathrm{s}}\right)=19 \mathrm{kN} / \mathrm{m}^{3}$, Unit Weight of concrete $\left(\gamma_{c}\right)=25 \mathrm{kN} / \mathrm{m}^{3}$, Bearing capacity of soil $\left(\sigma_{\mathrm{sbc}}=270 \mathrm{~N} / \mathrm{mm}^{2}\right.$, Concrete M20, Steel Fe 415 . 


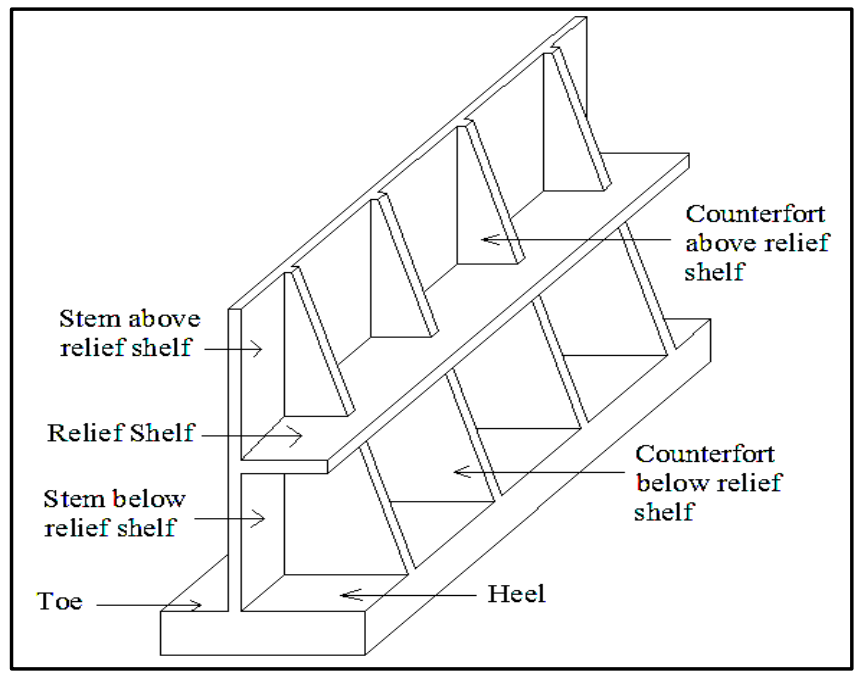

Fig.4 Counterfort retaining wall with one relief shelf

Following table shows dimensions of three different heights of wall.

Table -1: Dimensions of counterfort retaining wall

\begin{tabular}{|l|l|l|l|}
\hline \multirow{2}{*}{ Description } & \multicolumn{3}{|l|}{ Height of retaining wall } \\
\cline { 2 - 4 } & $\mathbf{1 0} \mathbf{~ m}$ & $\mathbf{1 2} \mathbf{~ m}$ & $\mathbf{1 5 ~ \mathbf { ~ }}$ \\
\hline Width of stem & $300 \mathrm{~mm}$ & $300 \mathrm{~mm}$ & $300 \mathrm{~mm}$ \\
\hline Width of counterfort & $300 \mathrm{~mm}$ & $300 \mathrm{~mm}$ & $300 \mathrm{~mm}$ \\
\hline Thickness of base slab & $1.25 \mathrm{~m}$ & $1.5 \mathrm{~m}$ & $1.8 \mathrm{~m}$ \\
\hline Width of base slab & $5.7 \mathrm{~m}$ & $6.8 \mathrm{~m}$ & $8.4 \mathrm{~m}$ \\
\hline Toe projection & $1.6 \mathrm{~m}$ & $1.8 \mathrm{~m}$ & $2.45 \mathrm{~m}$ \\
\hline Heel projection & $3.8 \mathrm{~m}$ & $4.7 \mathrm{~m}$ & $5.65 \mathrm{~m}$ \\
\hline Thickness of shelf & $400 \mathrm{~mm}$ & $500 \mathrm{~mm}$ & $600 \mathrm{~mm}$ \\
\hline Spacing of counterfort & $3 \mathrm{~m}$ & $3.3 \mathrm{~m}$ & $3.5 \mathrm{~m}$ \\
\hline
\end{tabular}

After fixing dimensions of walls, analysis is done for different positions of relief shelf and effect on earth pressure and stability of wall is studied.

Table -2: Results of analysis of counterfort retaining wall with different positions of shelf

\begin{tabular}{|c|c|c|c|c|c|}
\hline $\begin{array}{l}\text { Ht. } \\
\text { of } \\
\text { wall }\end{array}$ & $\begin{array}{l}\text { Relief } \\
\text { Shelf } \\
\text { Position }\end{array}$ & $\begin{array}{l}\text { Earth } \\
\text { pressure } \\
(\mathrm{kN} / \mathrm{m})\end{array}$ & $\begin{array}{l}\text { Overtur } \\
\text { ning } \\
\text { moment } \\
(\mathrm{kN} \text { m) }\end{array}$ & $\begin{array}{l}\text { FOS } \\
\text { overtu } \\
\text { rning }\end{array}$ & $\begin{array}{l}\text { FOS } \\
\text { slidin } \\
\text { g }\end{array}$ \\
\hline \multirow[t]{5}{*}{$10 \mathrm{~m}$} & $h / 3$ & 185.73 & 592.05 & 5.1 & 2.36 \\
\hline & $h / 2$ & 160.77 & 617.48 & 4.89 & 2.73 \\
\hline & $2 \mathrm{~h} / 3$ & 162.8 & 735.52 & 4.11 & 2.7 \\
\hline & $5 \mathrm{~h} / 6$ & 191.84 & 887.03 & 3.42 & 2.3 \\
\hline & H/2 & 158.33 & 659.72 & 4.58 & 2.78 \\
\hline \multirow[t]{5}{*}{$12 \mathrm{~m}$} & $h / 3$ & 267.58 & 1023.23 & 5.068 & 2.379 \\
\hline & $h / 2$ & 231.56 & 1066.52 & 4.861 & 2.756 \\
\hline & $2 h / 3$ & 234.33 & 1269.83 & 4.091 & 2.73 \\
\hline & $5 \mathrm{~h} / 6$ & 275.9 & 1531.33 & 3.408 & 2.324 \\
\hline & $\mathrm{H} / 2$ & 228 & 1140 & 4.551 & 2.803 \\
\hline \multirow[t]{5}{*}{$15 \mathrm{~m}$} & $h / 3$ & 417.11 & 1996.95 & 4.875 & 2.273 \\
\hline & $h / 2$ & 361.38 & 2087.79 & 4.66 & 2.63 \\
\hline & $2 \mathrm{~h} / 3$ & 366.95 & 2491.3 & 3.913 & 2.596 \\
\hline & $5 \mathrm{~h} / 6$ & 433.83 & 3005.16 & 3.258 & 2.201 \\
\hline & $\mathrm{H} / \mathbf{2}$ & 356.25 & 2226.56 & 4.372 & 2.67 \\
\hline
\end{tabular}

Here check for tension at the base slab and safe bearing capacity is also taken and best suited position is found out. From above results when relief shelf position is at $\mathrm{h} / 2$ gets minimum earth pressure, minimum overturning moment and better stability.

Following graphs shows moment in each component of counterfort retaining wall for different positions of shelf.

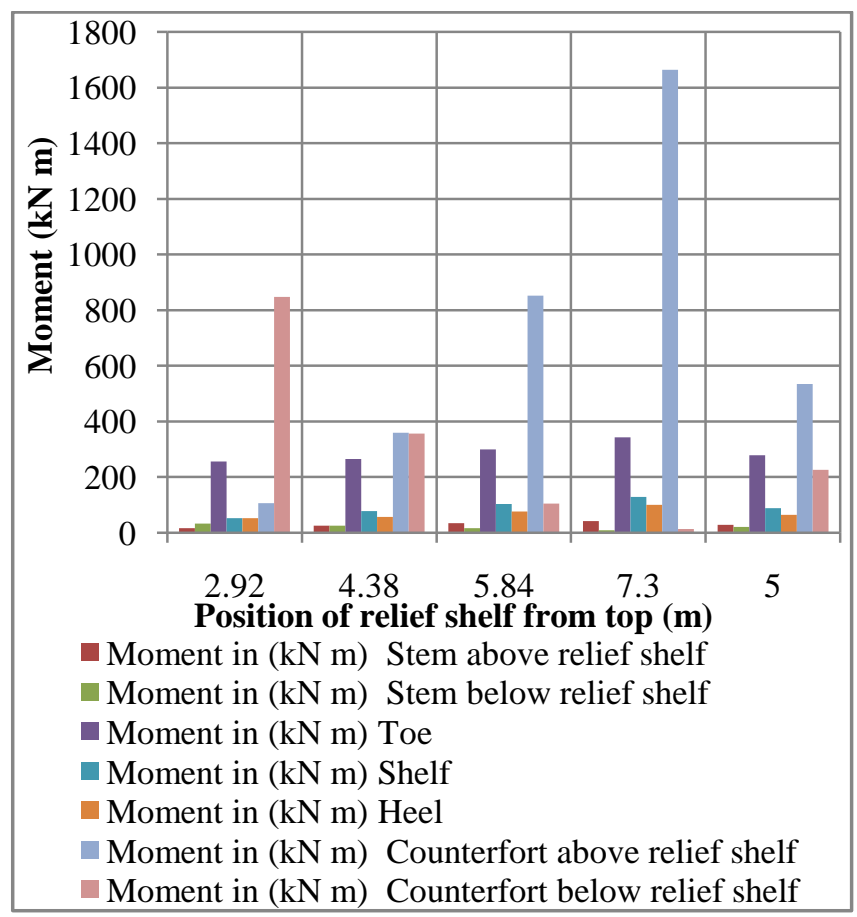

Chart -1: Moment in components of $10 \mathrm{~m}$ high counterfort retaining wall for different positions of relief shelf

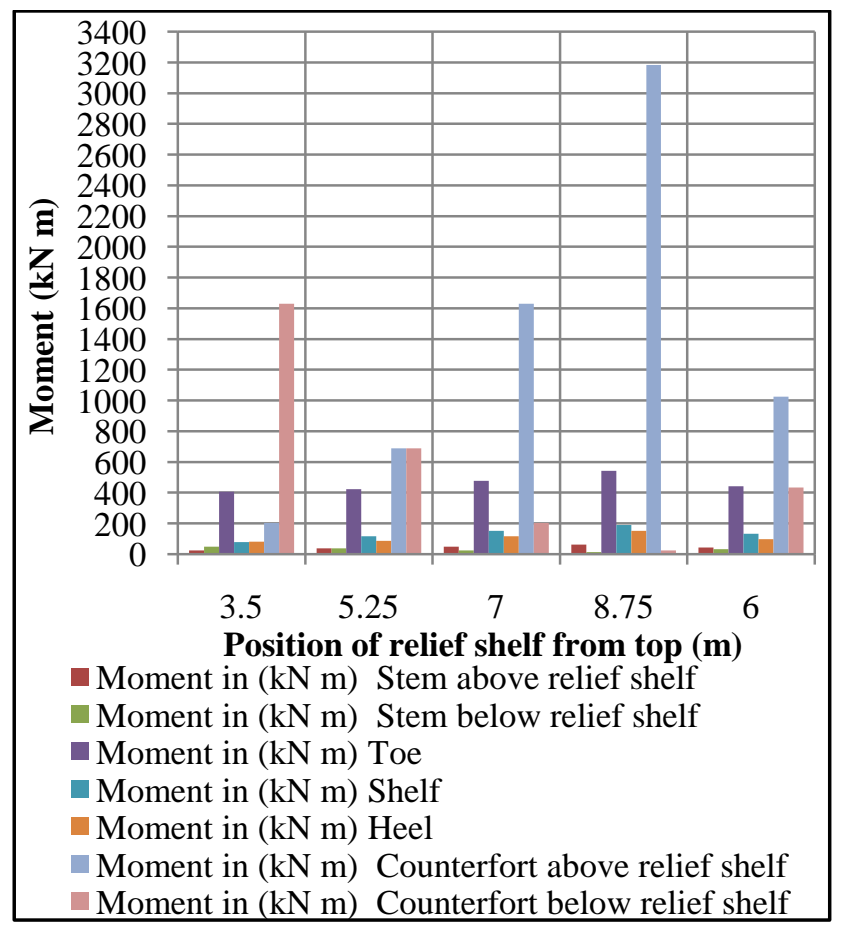

Chart -2: Moment in components of $12 \mathrm{~m}$ high counterfort retaining wall for different positions of relief shelf 


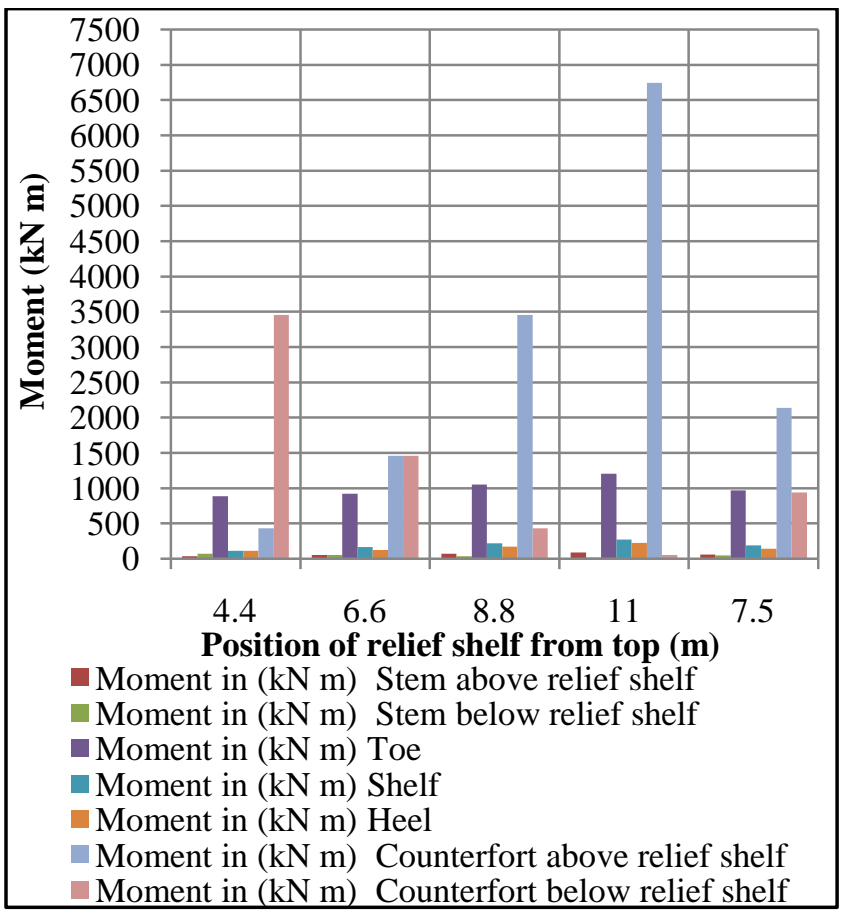

Chart -3: Moment in components of $15 \mathrm{~m}$ high counterfort retaining wall for different positions of relief shelf

From above graphs it is concluded that there is minimum moment in the components of retaining walls when shelf position is at $\mathrm{h} / 2$ height. ( $\mathrm{h}=$ height of stem.)

\section{OPTIMIZATION OF RETAINING WALL}

After fixing position of relief shelf, optimization of retaining wall is done to minimize the size. Following table shows optimized dimensions of retaining wall.

Table -3: Optimized dimensions of counterfort retaining wall

\begin{tabular}{|l|l|l|l|}
\hline \multirow{2}{*}{ Description } & \multicolumn{3}{|l|}{ Height of retaining wall } \\
\cline { 2 - 4 } & $\mathbf{1 0} \mathbf{~ m}$ & $\mathbf{1 2} \mathbf{~ m}$ & $\mathbf{1 5} \mathbf{~ m}$ \\
\hline Width of stem & $200 \mathrm{~mm}$ & $200 \mathrm{~mm}$ & $220 \mathrm{~mm}$ \\
\hline Width of counterfort & $300 \mathrm{~mm}$ & $300 \mathrm{~mm}$ & $300 \mathrm{~mm}$ \\
\hline Thickness of base slab & $0.6 \mathrm{~m}$ & $0.8 \mathrm{~m}$ & $1 \mathrm{~m}$ \\
\hline Width of base slab & $5 \mathrm{~m}$ & $5.8 \mathrm{~m}$ & $7.8 \mathrm{~m}$ \\
\hline Toe projection & $1.2 \mathrm{~m}$ & $1.8 \mathrm{~m}$ & $2.5 \mathrm{~m}$ \\
\hline Heel projection & $3.6 \mathrm{~m}$ & $3.8 \mathrm{~m}$ & $5.08 \mathrm{~m}$ \\
\hline Thickness of shelf & $250 \mathrm{~mm}$ & $280 \mathrm{~mm}$ & $320 \mathrm{~mm}$ \\
\hline Spacing of counterfort & $3 \mathrm{~m}$ & $3.3 \mathrm{~m}$ & $3.5 \mathrm{~m}$ \\
\hline
\end{tabular}

In following table stability checks are given

Table -4: Stability checks for counterfort retaining wall

\begin{tabular}{|l|l|l|l|l|}
\hline $\begin{array}{l}\text { Ht. } \\
\text { of } \\
\text { wall }\end{array}$ & $\begin{array}{l}\text { FOS against } \\
\text { Overturning }\end{array}$ & $\begin{array}{l}\text { FOS } \\
\text { against } \\
\text { Sliding }\end{array}$ & $\begin{array}{l}\mathbf{P} \mathbf{m a x} \\
\left(\mathbf{k N} / \mathbf{m}^{2}\right)\end{array}$ & $\begin{array}{l}\mathbf{P} \mathbf{m i n} \\
\left(\mathbf{k N} / \mathbf{m}^{\mathbf{2}}\right)\end{array}$ \\
\hline $\mathbf{1 0 ~ \mathbf { ~ }}$ & 3.612 & 2.411 & 213.37 & 93.15 \\
\hline $\mathbf{1 2} \mathbf{~ m}$ & 3.274 & 2.143 & 231.77 & 106.72 \\
\hline $\mathbf{1 5} \mathbf{~ m}$ & 3.761 & 2.271 & 249.74 & 167.00 \\
\hline
\end{tabular}

In the following table moment in each components of retaining wall and required steel for respective component are given

Table -5: Critical mmt in each component of counterfort retaining wall and their respective steel requirement

\begin{tabular}{|c|c|c|c|c|}
\hline $\begin{array}{l}\text { Compone } \\
\text { nt of wall }\end{array}$ & $\begin{array}{l}\text { Height of } \\
\text { wall }\end{array}$ & $10 \mathrm{~m}$ & $12 \mathrm{~m}$ & $15 \mathrm{~m}$ \\
\hline \multirow{2}{*}{ Stem } & $\begin{array}{l}\mathrm{Mu} \\
(\mathrm{kN} \mathrm{m})\end{array}$ & 27.12 & 39.90 & 56.75 \\
\hline & $\begin{array}{l}\text { Req }^{\mathrm{d}} \text {. Steel } \\
(\mathrm{mm} 2)\end{array}$ & 588.17 & 913.42 & 1156.16 \\
\hline \multirow{2}{*}{ Toe } & $\begin{array}{l}\mathrm{Mu} \\
(\mathrm{kN} \mathrm{m})\end{array}$ & 203.85 & 483.17 & 1012.03 \\
\hline & $\begin{array}{l}\operatorname{Req}^{\mathrm{d}} \text {. Steel } \\
(\mathrm{mm} 2)\end{array}$ & 478.51 & 1911.8 & 3211.04 \\
\hline \multirow{2}{*}{ Shelf } & $\begin{array}{l}\mathrm{Mu} \\
(\mathrm{kN} \mathrm{m})\end{array}$ & 82.74 & 121.59 & 172.70 \\
\hline & $\begin{array}{l}\mathrm{Req}^{\mathrm{d}} \text {. Steel } \\
(\mathrm{mm} 2)\end{array}$ & 1430.12 & 1856.7 & 2241.65 \\
\hline \multirow{2}{*}{ Heel } & $\begin{array}{l}\mathrm{Mu} \\
(\mathrm{kN} \mathrm{m})\end{array}$ & 91.53 & 141.84 & 158.72 \\
\hline & $\begin{array}{l}\mathrm{Req}^{\mathrm{d}} \text {. Steel } \\
(\mathrm{mm} 2)\end{array}$ & 478.51 & 539.31 & 472.85 \\
\hline \multirow{2}{*}{$\begin{array}{l}\text { Counterf } \\
\text { ort }\end{array}$} & $\begin{array}{l}\mathrm{Mu} \\
(\mathrm{kN} \mathrm{m})\end{array}$ & 443.84 & 834.17 & 1737.86 \\
\hline & $\begin{array}{l}\mathrm{Req}^{\mathrm{d}} \text {. Steel } \\
(\mathrm{mm} 2)\end{array}$ & 719.53 & 1242.7 & 1947.39 \\
\hline
\end{tabular}

\section{CONCLUSION}

Counterfort retaining wall of heights $10 \mathrm{~m}, 12 \mathrm{~m}$, and $15 \mathrm{~m}$ with relief shelf at $\mathrm{h} / 2$ gets minimum earth pressure, minimum overturning moment and better stability. (where $h=$ height of stem.)

Optimization of counterfort retaining wall is possible due to provision of relief shelf. Because of relief shelf moment in each component of retaining wall is reduced. It results in reduction in cross-section of retaining wall by $49.86 \%$ in 10 $\mathrm{m}, 49.84 \%$ in $12 \mathrm{~m}$ and $43.75 \%$ in $15 \mathrm{~m}$ height of wall. Due to reduction in cross-sectional area excessive cutting of earth mass is avoided and requirement of construction material is reduced, which results in reduction in construction cost.

\section{REFERENCES}

[1] Brig Rajesh Tyagi, "Construction of Retaining Structures in Bhutan" Journal of the Indian National Group of the International Association for Bridge \& Structural Engineering, March-April 2009.

[2] Bentler J.G., Labuz, J. F., "Performance of a cantilever retaining wall." Journal of geotechnical and geo environmental engineering, Page: 10621070, 2006.

[3] Chaudhuri P Ray, Garg A. K. "Design of retaining walls with relieving shelves" IRC Journal, Vol-35, page: 289 - 325,1973. 
[4] DonkadaShravya, MenonDevdas“"Optimal design of reinforced concrete retaining walls" The Indian Concrete Journal,April 2012.

[5] Dr. Punmia B. C. "Earth Pressure", Soil Mechanics and Foundations, Thirteenth Edition, Page- 535 581.

[6] I.S. 456:2000 Plain and Reinforced Concrete Code of Practice (Fourth Revision)

[7] Jumikis A.R., Mechanics of Soils, D Van Nostrand, 1964.

[8] Khural R. A "Design of modified retaining structures" The Bridge and Structural Engineering, Vol-43, Page: 31- 47,Mar2013.

[9] Natraja M. C. "Design and Detailing of Retaining Wall” April 2007.

[10] Padhye R. D, Ullagaddi P. B“Analysis of retaining wall with pressure relief shelf by coulomb's method" Proceedings of Indian Geotechnical Conference, Paper No. K-106, Page:671 - 673, 15-17 Dec2011.

[11] Patil S. M, Wagh K. S "Reduction in construction material: Effect of the provision of the loft behind the cantilever retaining wall" Indian Geotechnical Conference, Page:227-230,16-18Dec2010

[12] Ramamrutham S. And Narayan R. "Retaining Walls", Design of Reinforced Concrete Structures (Conforming To IS 456), Fifteenth Revised and Enlarged Edition, Page: 1236 - 1437.

[13] Sharma Chetan, Baradiya Vijay, "Evaluation of the effect of lateral soil pressure on cantilever retaining wall with soil type variation" IOSR Journal of Mechanical and Civil Engineering, Volume 11, Issue 2, Ver. III, Page: 36-42, Mar- Apr 2014.

\section{BIOGRAPHIES}

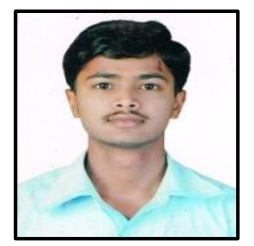

Tonne V. R, P.G (civil structure) Scholar, R. I. T. Sakharale, Sangli, Maharashtra, India

Email:gururaj.tonne@gmail.com

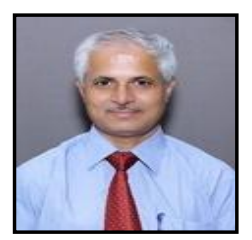

Mohite P. M, Associate Professor of Civil Engineering Department, R. I. T. Sakharale, Sangli, Maharashtra, India Email:prakash.mohite@ ritindia.edu 